\title{
Spectrophotometric Determination of Total Flavonoid Content in Biancaea Sappan (Caesalpinia sappan L.) Leaves
}

\author{
Nurlinda $^{1}$, Virsa Handayani ${ }^{1}$, Faradiba Abdul Rasyid ${ }^{1 *}$ \\ ${ }^{1}$ Department of Phytochemistry, Faculty of Pharmacy, Universitas Muslim Indonesia, Indonesia
}

\begin{tabular}{|c|c|}
\hline Article info & Abstract \\
\hline History & Biancaea sappan (BS) is traditionally used to treat anticonvulsants, anti- \\
\hline Submission: $17-06-2020$ & inflammatory, antiproliferative, anticoagulant, antiviral, immunostimulant, \\
\hline Review: 06-11-2020 & antioxidant, and antimicrobial. Flavonoids are found in Secang; flavonoids \\
\hline Accepted: 24-02-2021 & are secondary metabolites that have antioxidant activity. This study aims to \\
\hline $\begin{array}{l}\text { *Email: } \\
\text { faradiba.faradiba@umi.ac.id }\end{array}$ & $\begin{array}{l}\text { identify the flavonoids using TLC and determination of flavonoids content } \\
\text { in BS leaves. Initially, The methanol extract of BS was obtained by } \\
\text { maceration with ethanol. The qualitative analysis of flavonoid was using }\end{array}$ \\
\hline DOI: $10.33096 /$ jffi.v8i3.712 & $\begin{array}{l}\text { TLC and visualization by sprayed with } \mathrm{AlCl}_{3} \text {. The determination of total } \\
\text { flavonoid content is conducted based on the AlCl3 method with total }\end{array}$ \\
\hline Keywords: & flavonoids expressed in $Q E$ (Quercetin equivalent) at the maximum \\
\hline $\begin{array}{l}\text { Caesalpinia sappan; Flavonoid } \\
\text { content; } \text { Spectrophotometric }\end{array}$ & $\begin{array}{l}\text { wavelength of } 431 \mathrm{~nm} \text {. The research results showed that BS leaves contain } \\
\text { flavonoids and the total flavonoid content of BS leaf extract is } 1.0318 \mathrm{mg} \\
Q E / g \text { extract. }\end{array}$ \\
\hline
\end{tabular}

\section{Introduction}

Indonesia is one of the mega diversity countries for medicinal plants in the world. Indonesia's tropical forest area has the secondhighest biodiversity in the world after Brazil. Of the 40,000 species globally, 30,000 in Indonesia, and 940 have medicinal properties used in traditional medicine from generation to generation by various ethnic groups in Indonesia. The number of medicinal plants covers about $90 \%$ of the total number of medicinal plants found in the Asian region (Pertamawati et al., 2017).

Flavonoid compounds are the largest group of phenolic compounds found in nature. These compounds are red, purple, blue and some yellow dyes found in plants (Andersen and Markham, 2005). Several medicinal plants containing flavonoids have antioxidant, antibacterial, antiviral, anti-inflammatory, allergy, and anticancer activities (Miller and Begoña Ruiz-Larrea, 2002). Flavonoid compounds are thought to be very useful in food because, in the form of phenolic compounds, these compounds are potent antioxidants. Many disease conditions are known to be exacerbated by the presence of free radicals such as superoxides and hydroxyl, and flavonoids can virtually eliminate these damaging oxidizing species (Heinrich, M, Bames, J, Gibbons, S, Williamson, E, 2010).

In the previous research, Setiawan had carried out the antioxidant activity test of BS wood extract (Setiawan, Yunita and Kurniawan, 2018). In this test, phytochemical screening was also carried out in which the BS wood was positive for flavonoids. Flavonoid compounds had found in all plants, including seeds, roots, fruits, fruit skins, leaves, and stems (Harbone, 1987). Based on that theory, the levels of flavonoids contained in BS leaves can be determined. Flavonoids are among the most extensive natural phenolic group antioxidant compounds and are present in all plants to ensure flavonoids in plants.

Quantitative analysis of flavonoids could perform using UV-VIS spectrophotometry. Ultraviolet absorption and visible absorption spectrum are ways to identify flavonoids' structure (Andersen and Markham, 2005) Flavonoids contain a conjugated the aromatic chemical structure can show a strong absorption band in the UV-VIS area (Mukhriani, Nonci and Munawarah, 2015).

Based on the description above, this research was conducted to determine the flavonoid levels of BS leaf extract (Caesalpinia sappan L.) to increase scientific data from medicinal plants.

\section{Research Method}

\section{II.1 Preparation of Biancaea Sappan Leaves Powder}

Samples of BS (Caesalpinia sappan L.) leaves which have been taken, then cleaned by washing with running water, then dried in a drying cabinet with $40-50^{\circ} \mathrm{C}$ temperature. After that, it is powded using a blender, and then the sample is ready to be extracted (Rasyid et al., 2017).

\section{II.2 Preparation of Methanol Extract Biancaea Sappan Leaves}

The fresh leaves were minced into small pieces and macerated with methanol $(1: 20, \mathrm{w} / \mathrm{v})$ for $72 \mathrm{~h}$ at room temperature $\left(28 \pm 2{ }^{\circ} \mathrm{C}\right)$ with occasional stirring. The extract was filtered, and the marc was re-macerated with the same solvent until the 
extraction was exhausted. The filtrate obtained from the maceration results is combined, then evaporated with a rotary evaporator (Handayani, Kurniawati and Abdul Rasyid, 2020).

\section{II.3 The Qualitative analysis of Flavonoid in Methanol Extract Biancaea Sappan Leaves}

The qualitative test of flavonoids, thin layer chromatography analysis was performed. BS leaf extract was dissolved with acetone and then spotted on the TLC plate. The plates were inserted in the chamber containing the eluent n-hexane: ethyl acetate (9: 1), then observed under UV254 and UV366 nm. Then sprayed with specific reagents. The reagents often used to identify flavonoids as spray reagents in thin layer chromatography are $\mathrm{AlCl} 3$, which give a yellow color (Ahmad, Juwita and Ratulangi, 2015), (R, Dahlia and Ahmad, 2016).

\section{II.4 The Quantitative analysis of Flavonoid in Methanol Extract Biancaea Sappan Leaves II.4.1 Preparation of Standard Solution}

$10 \mathrm{mg}$ of standard quercetin standard was weighed and dissolved in $10 \mathrm{~mL}$ of methanol p.a for 1000 ppm concentration. The stock solution of 1000 ppm quercetin, pipetted $1 \mathrm{~mL}$ and dissolved in 10 $\mathrm{mL}$ of methanol p.a to obtain $100 \mathrm{ppm}$, then made several concentrations of $4 \mathrm{ppm}, 5,6 \mathrm{ppm}, 7 \mathrm{ppm}$, and $8 \mathrm{ppm}$. From each concentration of the quercetin standard solution, $3 \mathrm{~mL}$ of methanol, $0.2 \mathrm{~mL}$ of $10 \%$ $\mathrm{AlCl} 3,0.2 \mathrm{~mL}$ of $1 \mathrm{M}$ potassium acetate were added, and add aquadestilata up to $10 \mathrm{~mL}$, incubated for 30 minutes at room temperature. The absorbance was measured on UV-Vis spectrophotometry with a wavelength of $431 \mathrm{~nm}$. (Aminah, Tomayahu and Abidin, 2017).

\section{II.4.2 Determination of Flavonoid compound of BS Leaf extract}

$25 \mathrm{mg}$ of the extract was weighed, dissolved in $10 \mathrm{~mL}$ ethanol to obtain a concentration of $2500 \mathrm{ppm}$. $1 \mathrm{~mL}$ was pipetted from the solution, then add $3 \mathrm{~mL}$ of methanol, $0.2 \mathrm{~mL}$ of $10 \% \mathrm{AlCl} 3$ and $0.2 \mathrm{~mL}$ of $1 \mathrm{M}$ potassium acetate, and $10 \mathrm{~mL}$ of aquadestilata. Samples were incubated for 30 minutes at room temperature. The absorbance was measured on UV-Vis spectrophotometry at a wavelength of $431 \mathrm{~nm}$; the samples were made in three replications for each analysis mean absorbance value was obtained. The level of flavonoids can be calculated using the following formula:

Total Flavonoid =

V.Sample $\mathrm{x}$ Initial Concentration (x) x DF Sample weight

\section{Results and Discussion}

BS (Caesalpinia sappan L.) plant is one of the plants empirically used as a treatment. Based on previous research, BS plants are anticonvulsant, anti-inflammatory, antiproliferative, anticoagulant, antiviral, immunostimulant, antioxidant antimicrobial (Kusmiati, Dameria and Dody Priadi, 2016). Besides, BS is also used to treat diarrhea, dysentery, coughing up blood in tuberculosis, vomiting blood, syphilis, malaria, tetanus, swelling (tumors), and pain due to blood circulation disorders (Dianasari, 2009).

BS leaves have different chemical contents; one of them is flavonoids. Flavonoids are chemical compounds found in almost all plants, namely roots, stems, leaves, fruits, and seeds. Some plants that contain flavonoids have antioxidant, antibacterial, antiviral, anti-inflammatory, antihistamine, and anticancer activity (Ahmad et al., 2015). $100 \mathrm{~g}$ of BS (Caesalpinia sappan L.) leaf sample extracted by maceration using $2.75 \mathrm{~L}$ methanol to obtain $10.063 \%$ yield value.

The results of extracting samples of BS leaves (Caesalpinia sappan L.) can be seen in the Table 1 .

Table 1. Yield value of BS (Caesalpinia sappan L.) leaves extract

\begin{tabular}{lllll}
\hline Sample & Sample weight $(\mathbf{g})$ & $\begin{array}{l}\text { Amount of Solvent } \\
(\mathbf{L})\end{array}$ & $\begin{array}{l}\text { Extract result } \\
(\mathbf{g})\end{array}$ & Yield value \\
\hline $\begin{array}{l}\text { BS } \\
\text { Leaves }\end{array}$ & 100 & 2,75 & 10,063 & 10,063 \\
\hline
\end{tabular}

A qualitative test was performed to determine the sample's chemical components using the thin layer chromatography (TLC) method and the result can be seen in the Table 2. The sample extract of BS (Caesalpinia sappan L.) leaves dissolved with acetone because acetone is a polar compound, so it is expected to attract polar flavonoids. Besides, acetone is also volatile so that when it is placed on the TLC plate, the solvent can quickly evaporate (Saputra, 2015). 
Table 2. Qualitative test Results of BS leaf (Caesalpinia sappan L.) extract flavonoid compound using TLC

\begin{tabular}{llll}
\hline Sample & $\begin{array}{l}\text { Flavonoid } \\
\text { test }\left(\mathbf{A l C l}_{3}\right)\end{array}$ & $\begin{array}{l}\text { Reference } \\
(\text { Ahmad, 2015) }\end{array}$ & Result \\
\hline BSLeaf & Yellow & Yellow & + \\
\hline Note: + (contains flavonoid) & &
\end{tabular}

Quantitative analysis of total flavonoid compounds using UV-Vis spectrophotometry was carried out to determine the total flavonoid levels contained in BS (Caesalpinia sappan L.) leaf extract. Flavonoid analysis was carried out using $\mathrm{UV}-\mathrm{Vis}$ spectrophotometry because flavonoids have conjugated aromatic systems to show strong absorption bands in the ultraviolet light spectrum and visible light spectrum, because quercetin is a type of flavonoid that is commonly used as a standard in determining levels of flavonoids, quercetin is a class of flavonols that is widespread in plants; besides, flavonols have a keto group found in $\mathrm{C}-4$ and a hydroxyl group on $\mathrm{C}-3$ or $\mathrm{C}-5$ atoms they can form complexes with $\mathrm{AlCl}_{3}$ (Ipandi, Triyasmono and Prayitno, 2016). In this study, quercetin was used to determine total flavonoid levels as a standard solution. The result of the quercetin absorbance with concentration 4 ppm, 5 ppm, 6 ppm, 7 ppm and 8 ppm can be seen in the Table 3. Quercetin was used as a standard to establish calibration linear with function, which can been seen in Figure 3.

Table 3. Results of quercetin absorbance measurements at $431 \mathrm{~nm}$

\begin{tabular}{cc}
\hline $\begin{array}{c}\text { Concentration } \\
(\mathbf{p p m})\end{array}$ & Absorbance \\
\hline 4 & 0,398 \\
5 & 0,505 \\
6 & 0,593 \\
7 & 0,709 \\
8 & 0,829 \\
\hline
\end{tabular}

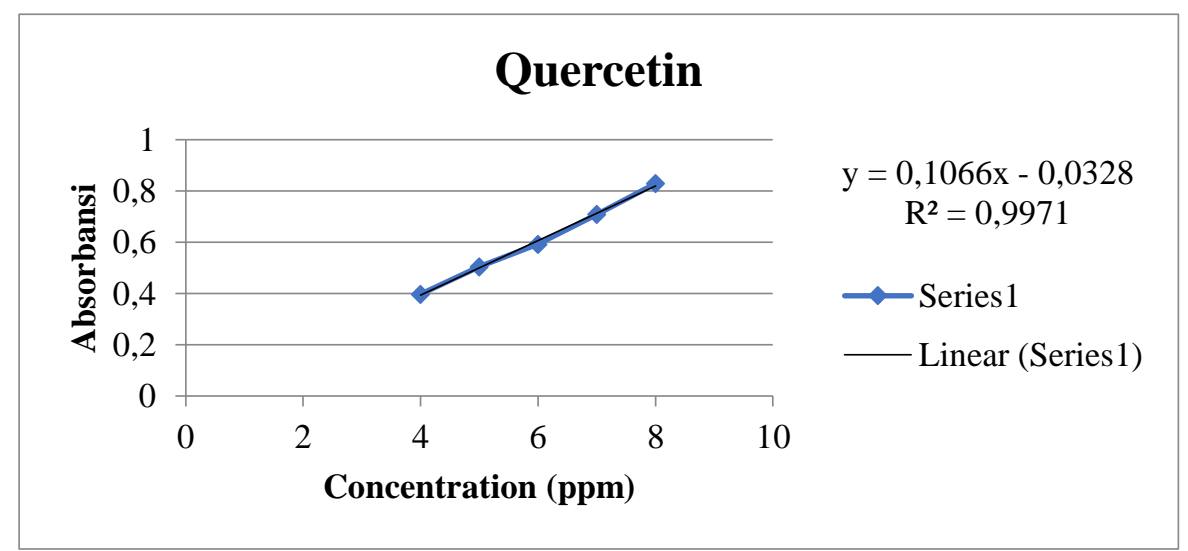

Figure 1. Quercetin calibration curve at a maximum wavelength of $431 \mathrm{~nm}$

In measuring the total flavonoid content of BS (Caesalpinia sappan L.) leaf extract, $25 \mathrm{mg}$ of BS leaf extract were weighed then dissolved with 10 $\mathrm{ml}$ p.a methanol. Then take $1 \mathrm{~mL}$ and then add $3 \mathrm{ml}$ of methanol pa, $0.2 \mathrm{~mL}$ of $10 \% \mathrm{AlCl}_{3}$ which can form a complex, resulting in a shift in the wavelength towards the visible (visible) and marked with a solution producing a intensively yellow color, then add $0.2 \mathrm{~mL}$ of potassium acetate to maintain the wavelength in the visible area, then add up to $10 \mathrm{~mL}$ of aquadestilata. The mixture is incubated at room temperature for 30 minutes; the mixture is incubated for 30 minutes to make the reaction runs perfectly so that the resulting color intensity is more (Ahmad, Juwita and Ratulangi, 2015). They are then measured at a wavelength of $431 \mathrm{~nm}$. The measurement results can be seen in Table 4 .

Table 4. Determination of Total Flavonoid Levels of BS (Caesalpinia sappan L.) leaf extract

\begin{tabular}{cccccc}
\hline Sample & Replication & Absorbance & $\begin{array}{c}\text { Initial } \\
\text { Flavonoid } \\
\text { Content } \\
\text { (mg/ml) }\end{array}$ & $\begin{array}{c}\text { Total Flavonoid } \\
\text { Content (mgQE/g eks) }\end{array}$ & $\begin{array}{c}\text { Total Flavonoid } \\
\text { Content average } \\
\text { mgQE/g ekss }\end{array}$ \\
\hline \multirow{3}{*}{ BSLeaves } & 1 & 0,262 & 0,002773 & 1,1092 & 1,0318 \\
& 2 & 0,234 & 0,002509 & 1,0016 & 0,9848 \\
\hline
\end{tabular}

The total flavanoid content of BS was calculated from the calibration plot of the linear regression equation $(\mathrm{Y}=0.1066 \mathrm{X}-0.0328, \mathrm{R}=$
0,997) which stated as $\mathrm{mg}$ quercetin equivalent (QE)/g of dried plants materials (Chandra et al., 2014). Based on the results, the total flavonoid 
content of BS leaf extract (Caesalpinia sappan L.) was $1.0318 \mathrm{mg} \mathrm{QE} / \mathrm{g}$.

\section{Conclusions}

Based on the research results, it can be concluded that the total flavonoid level of BS leaf extract (Caesalpinia sappan L.) is $1.0138 \mathrm{mg} \mathrm{QE} / \mathrm{g}$.

\section{Acknowledgment}

The authors gratefully thank Pharmacy's faculty, Universitas Muslim Indonesia Makassar, for all the facilities used for this research.

\section{References}

Ahmad, A. R., Juwita, J. and Ratulangi, S. A. D. (2015) 'Penetapan Kadar Fenolik dan Flavonoid Total Ekstrak Metanol Buah dan Daun Patikala (Etlingera elatior (Jack) R.M.SM)', Pharmaceutical Sciences and Research, 2(1), pp. 1-10. doi: 10.7454/psr.v2i1.3481.

Aminah, A., Tomayahu, N. and Abidin, Z. (2017) 'Penetapan Kadat Flavaonid Totak Ekstrak Etanol Kulit Buah Alpukat (Persea americana Mill.) dengan Metode Spektrofotometri UV-VIS', Jurnal Fitofarmaka Indonesia, 4(2), pp. 226-230. doi: 10.33096/jffi.v4i2.265.

Andersen, Ø. M. and Markham, K. R. (2005) Flavonoids: Chemistry, Biochemistry and Applications. 1st Editio, CRC Press. 1st Editio. doi: 10.1201/9781420039443.

Chandra, S. et al. (2014) 'Assessment of total phenolic and flavonoid content, antioxidant properties, and yield of aeroponically and conventionally grown leafy vegetables and fruit crops: A comparative study', Evidence-based Complementary and Alternative Medicine, 2014. doi: $10.1155 / 2014 / 253875$.

Dianasari, N. (2009) Uji Aktivitas Antibakteri Ekstrak Etanol Kayu Secang (Caesalpinia sappan L.) terhadap Staphylococcus aureus dan Shigella dysentriae serta Bioautografinya.

Universitas Muhamamdiyah Surakarta.

Handayani, S., Kurniawati, I. and Abdul Rasyid, F. (2020) 'Uji Aktivitas Antioksidan Ekstrak Daun Karet Kebo (Ficus Elastica) dengan Metode Peredaman Radikal Bebas Dpph (1,1-Diphenyl-2-Picrylhydrazil)', Jurnal Farmasi Galenika (Galenika Journal of Pharmacy) (e-Journal). doi: 10.22487/j24428744.2020.v6.i1.15022.

Harbone, J. . (1987) Metode Fitokimia. Bandung: Penerbit ITB, Bandung.

Heinrich, M, Bames, J, Gibbons, S, Williamson, E, M. (2010) Farmakognosi dan Fitoterapi. Jakarta: Penerbit Buku Kedokteran.

Ipandi, I., Triyasmono, L. and Prayitno, B. (2016) 'Penentuan kadar flavonoid total dan aktivitas antioksidan ekstrak etanol daun kajajahi (Leucosyke capitellata Wedd.)', Jurnal Pharmascience, 3(1), pp. 93-100.

Kusmiati, Dameria and Dody Priadi (2016) 'Analisa Senyawa Aktif Ekstrak Kayu Secang (Caesalpinia sappan L.) yang Berpotensi Sebagai Antimikroba', Seminar Nasional Teknologi Industri Hijau 1, (May).

Miller, N. J. and Begoña Ruiz-Larrea, M. (2002) 'Flavonoids and other plant phenols in the diet: Their significance as antioxidants', Journal of Nutritional and Environmental Medicine. doi: 10.1080/13590840220123352.

Mukhriani, Nonci, F. and Munawarah, S. (2015) 'Analisis Kadar Flavonoid Total Pada Ekstrak Daun Sirsak (Annona muricata L.) Dengan Metode Spektrometri UV-Vis', Jf Fkik Uinam, 3(1), pp. 37-42.

Pertamawati, P. et al. (2017) 'Konsumsi Ekstrak Secang (Caesalpinia sappan L.) Terhadap Volume Urin Tikus Putih Jantan Galur Spraque Dawley', Jurnal Jamu Indonesia. doi: 10.29244/jji.v2i3.41.

R, R. Y., Dahlia, A. A. and Ahmad, A. R. (2016) 'Penetapan Kadar Flavonoid Total Dari Ekstrak Etanolik Daun Benalu Mangga (Dendrophthoe pentandra L. Miq)', Jurnal Fitofarmaka Indonesia, 1(1), pp. 14-17. doi: 10.33096/jffi.v1i1.195.

Rasyid, F. A. et al. (2017) 'A novel clerodane diterpene from Vitex cofassus', Chemical and Pharmaceutical Bulletin. doi: 10.1248/cpb.c16-00775.

Saputra, A. (2015) Uji Aktivitas Antiinflamasi Ekstrak Etanol 96\% Kulit Batang Kayu Jawa (Lannea coromandelica) Dengan Metode Stabilisasi Membran Sel Darah Merah Secara In Vitro. UIN Syarif Hidayatullah Jakarta. Available at: http://repository.uinjkt.ac.id/dspace/bitstre am/123456789/29081/1/ANDIS SAPUTRA-FKIK.pdf.

Setiawan, F., Yunita, O. and Kurniawan, A. (2018) 'Uji Aktivitas Antioksidan Ekstrak Etanol Kayu Secang dan FRAP', Media Pharmaceutica Indonesiana, 2(2), pp. 8289. 